\title{
Speaking for Academic Purposes Course: An Analysis of Language Functions
}

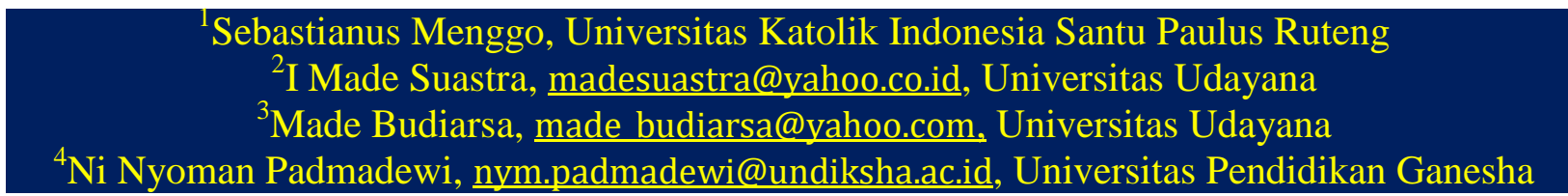

*Corresponding Author: Sebastian.pradana@gmail.com

\section{Received Date: 10-02-2019 Accepted Date: 28-03-2019 Published Date: 31.-07-2019}

Abstract - Speaking as the most demanding skill to be mastered in the ESL/EFL teaching context. This is caused by the prime priority of students who want to study English in order to be able to use English for communicative purposes. Knowledge of language functions has a vital role in supporting a speaker to be more involved in the real interaction. The aims of this study are to identify and analyze the kinds of language functions and how their use in the speaking for academic purposes course. This study was conducted at Universitas Katolik Indonesia Santu Paulus Ruteng, Flores. The data were taken from 33 English department students who were doing the English speaking exercises at the speaking for academic purposes course. The data were collected through observation, field note and recording during eight meetings on October- November 2018 and only language functions utterances of those respondents were analyzed. The recorded utterances are expected to be representative of the whole the language functions. Utterances produced by respondents were recorded precisely by the researchers. The result showed that there are five types of language functions found, namely interactive function, informative function, manipulative function, motivative function and directive functions. Those functions are reciprocal. Speaking practitioners are suggested to provide the knowledge of language functions in the speaking learning process.

Keywords: academic-English speaking, language function, teaching

\section{Introduction}

Become a competent English speaker is the prime orientation for many English as a Foreign/Second Language (EFL/ESL) learners. English learners sometimes evaluate their success in the English learning based on how well they have improved in their spoken ability (Leong \& Ahmadi, 2017). Consequently, English teachers are expected to design the speaking activities which enable learners working together to share their thoughts, questions, ideas and solutions in a number of speaking tasks and exercises. Those help the learners to develop and achieve their English communication skills (Menggo, Suastra, Budiarsa \& Padmadewi, 2019). 
Strong English speaking ability supports communication skill achievement (Menggo, 2018). Accordingly, speaking is viewed as a skill in conveying information, ideas or concepts to the interlocutor. Menggo further claimed that strong speaking ability is not only determined by mastery of grammar but also how accurate and clear an English speaker produces the words, phrases, or sentence by sentence in the speech of information. In line with Menggo's finding, (Imaniah \& Dewi, 2017) claimed that the achievement of speaking ability is indicated by how a speaker is able to convey information or message both verbally and non-verbally to the interlocutor clearly and acceptably. They further describe that in terms of linguistic competence, a speaker is strongly advised to possess the lexicon production, morphology, syntax, semantics, the phonetics, phonology insights, and a sundry of language functions such as emotive, informative, referential, phatic, conative, and so forth in supporting the acceptableness of the utterances produced in the real communication.

Knowledge of language functions enables an English speaker to be actively involved in the real communication. It helps a speaker to describe the certain concepts or ideas present in the speaker's mind and express name of things and describe processes in the outer world (Parpalea, 2011). On the contrary, Parpalea affirmed that communication could hardly be successful unless the utterance was accompanied by certain concepts of language functions.

Previous researches about language functions have been integrated in daily life, including in the speaking courses (Lestari, Suastra, Pastika \& Sedeng, 2017; Tribus, 2017). They claimed that knowledge of language functions can help the English learners to enhance their English speaking competence and become more participative in a number of language activities. Knowledge of language functions affects the English communicative competence.

Although previous researches present convincing evidence that knowledge of language functions must be provided by speaking practitioners in order to cope better toward learners' communicative competence, promote learners' learning outcomes, stimulate learners' interest and to raise their attention on the application of language functions in producing the utterances (Azizifard \& Jalali, 2012), the concept of language functions in the speaking for academic purposes course has not been strongly supported by recent language functions in the speaking courses research findings. 
While the assumption that concept of language functions in the speaking for academic purposes is an essential factor for learners' success in the communication achievement, including metaphorical expressions, such as informational function, expressive function, directive function, pathetic function and aesthetic function ( Sarwadi, Yadnya, Beratha \& Puspani, 2019). In this paper, the concept of language functions in supporting learner's communication achievement is highly supported.

Two studies have provided evidence that concept of language functions in the speaking courses is vitally important for success in the communication skill demand (Lestari, 2017). She found out that there are six types of the language functions in promoting learner's communication ability, namely permissive function (to soften utterances, to avoid repetition, and to adjust intonation); interactive function (to greet, to have small talks, and farewell); informative function (to introduce, to show, to state, to explain, to ask, to agree, to reject, and to confirm); persuasive function (to offer, to promise, to suggest, and to persuade); directive function (to tell, to order, and to request) and indicative function (to praise, to complain, to thank, and to apologize). This aligns with research finding conducted by Dickinson (2013) who claimed that four major functions of language in terms of oral communication, they are, to manipulate situations, to assert individual identity, to assert group identity and to connect the meaning and structure of the discourse. Those functions play important role in the achievement of oral communication ability.

\section{Research Problem}

Reference to the aforementioned, the researchers formulated the research question as follows: What are the types of language function used in the speaking for academic purposes course?

\section{Research Objective}

Based on the research problem above, the researchers attempted to identify and analyze the types of language functions and how their use in the speaking for academic purposes course.

\section{Theoretical Framework}

\subsection{Speaking for Academic Purposes Course}

The Ministry of Research, Technology and Higher Education of the Republic Indonesia has legalized Indonesian qualification frameworks which aim to manage Indonesian qualification standards for higher education throughout Indonesia. An Indonesian qualification framework has

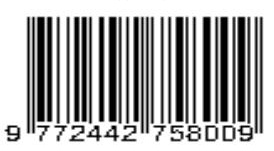


categorized three types of speaking subjects include informal speaking, formal speaking and speaking for academic purposes (Kemenristekdikti, 2012). The learning outcome of informal speaking is students are able to speak English at the pre-intermediate level in informal interaction settings, formal speaking encourages students to be able to speak English in the formal interaction settings. Then, speaking for academic purposes students are boosted to speak English at the advanced level fluently, accurately, and acceptably by using a several of language functions in formal activities.

This research merely focused on the speaking for academic purposes. The understanding of language functions can motivate, involve and help students to think and learn based on this advance outcome.

Learners unaware of the importance of talk for learning may think of talk as just usual chat - and learning falls away as they slip into social talk. This notion engages speaking skill is significantly to be mastered by ESL/EFL learners (Harmer, 2007: 123). Further Harmer said that speaking is a skill to convey thought, idea or opinion precisely toward interlocutor. Similarly, Kayi (2006: 1) defines speaking as the process of building and sharing meaning through the use of verbal and non-verbal symbols in a variety of contexts. Moreover, Celce-Murcia (2001: 112) states that speaking is a mean of communication in which there are two ways relationship between speakers and listeners, which has certain purposes either in social life interaction or pedagogy of the classroom interaction.

Tarigan (2015:16) defines speaking skill as an ability to verbalize articulation sounds or words to express, convey thought, notion and feeling. A speaker is sued to convey the thought effectively; therefore she/he must understand what will be communicated. A speaker must be able to evaluate his/her communication effect toward interlocutor and know the basic principles in the communication either generally or personally. Then, Atkinson (1985) said that speaking is a skill in conveying information, ideas or concepts to the listener. A speaker is strongly suggested to understand some important components to make the message ca be easily understood by interlocutor, such as (1) the utterance or pronunciation of speaker should be clear and accurate; (2) conveying the ideas must be in the complete sentences. It must be clear the position of main idea and supporting ideas in the utterance; (3) a speaker must be able to develop main idea by providing the examples; (4) the utterances delivered are in line with interlocutor's

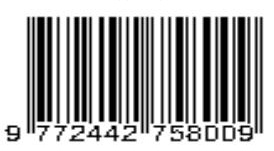


cognition rank; and (5) a speaker may use verbal and non-verbal communications in assisting interlocutor's comprehension.

In achieving the learning outcome of speaking for academic purposes course, a speaker should understand micro and macro skills of speaking itself (Brown, 2004:142-143). Brown further described about micro skills in speaking are (1) speaker is able to produce chunks of language of different lengths, orally producing differences among English phoneme and allophonic variants; (2) be able to produce English stress pattern, words in stressed and unstressed position, rhythmic structure, and intonation contours; (3) be able to produce reduced forms of words and phrases, using and adequate number of lexical units (words) in order to accomplish pragmatic purposes, producing fluent speech at different rates of delivery; (4) be able to monitor one's own oral production and use various strategies devices-pauses, filler, self correction, backtracking to enhance the clarity of the message; (5) be able to use grammatical words lasses (noun, verb, etc), system (e.g. tense, agreement, pluralization, word order, pattern, rules, and elliptical forms; (6) be able to produce speech in natural constituents in appropriate phrases, phrases, pauses group, and sentences, expressing a particular meaning in different grammatical forms; (7) be able to use cohesive devices in spoken discourse.

Moreover, the macro skills in speaking are (1) speaker is able use appropriate styles, registers, implicature, redundancies, pragmatic conventions, and conventions rules, floor keeping and yielding, interrupting, and other sociolinguistics features in face to face conversations; (2) be able to convey the links and connections between events communicate such relations as focal and peripheral ideas, events and feeling, supporting ideas of new information and given information, generalization and exemplification; (3) be able to use facial features, kinesics, body language, and other nonverbal cues along with the verbal language to convey meanings; and (4) be able to develop and use a battery of speaking strategies, such as emphasizing key words, rephrasing, providing a context for interpreting the meaning of words, appealing for help, and finding how well one's interlocutor is understanding other.

\subsection{Language Functions}

The achievement of speaking skill ability as stated is needed to be propped by the understanding of language function. Knowledge of language function is believed as strong basis for a speaker to achieve his/her speaking ability. Brown (2007: 223) said that prime function of

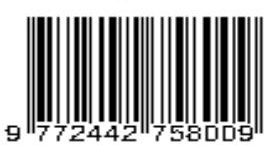


language function is to know the goal which wants to be achieved with that language, for example expressing, asking, responding, greetings, saying farewell, and so forth.

Linguist Jakobson (1987: 65-72) classified six types of language functions, namely emotive, conative, referential, poetic, phatic and metalingual. These language functions refer to addresser, addressee, context, message, contact and code. Jakobson further affirmed that there is inter-dependency among functions in producing the utterances. Nevertheless, there is an opportunity to appear a certain function in the real interaction.

Language functions in this research refer to language functions proposed by Leech (1974), namely (1) informational function which is used for conveying information; (2) expressive function which is used for expressing feelings of a speaker; (3) directive function which is used for getting interlocutor does something for a speaker; (4) aesthetic function which is used for describing the language itself, example in the poems; and (5) phatic function which is used for maintaining the interaction between participants. These five types of language functions always used in daily life which refer to (1) subject matter; (2) speaker; (3) interlocutor, (4) media used and (5) message delivered.

\section{Research Method}

The design of this study was descriptive-qualitative. The population of the research was 66 students from two classes who enrolled in speaking for academic purposes course at the English department of Universitas Katolik Indonesia Santu Paulus Ruteng, Flores. A total of 33 students at this college were selected as sample by using purposive technique. The data were collected through observation, field note and recording. The recording was done during respondents practicing the English speaking exercises at the speaking for academic purposes course. This data collection was taken during eight meetings from October - December 2018 and only language functions utterances of those respondents were analyzed. Researchers observed, noted and recorded precisely the variety of utterances produced by respondents. The data obtained categorized according to the language function.

\section{Result and Discussion}

Students' oral conversations during eight meetings from October - December 2018 in the speaking academic purposes course were used as source of data used by the researchers in analyzing the language functions. Speaking exercises data were described inductively, where a 
sundry of the language functions analyzed based on participants' utterances. There were five types of language functions found in the speaking for academic purposes manuscript, namely interactive function, informative function, manipulative function, motivative function and directive function. There was found the inter-dependency of those language functions in the real interaction. Each of those can be described as follows.

\subsection{Interactive Function}

The aim of this function is the inter-relation between participants. The data below were taken from the first and second speaking exercises about religion tolerance and teenager's life style topics which uttered by five participants.

\section{Data 1}

Maria : Hello Yuven, good morning.

Yuven : Good morning Maria. How are you this morning?

Maria : Yah...fine. What about you?

Yuven : Everything is running well for me.

Maria $\quad$ :Oh.... I am pleased to hear that. Yuven, do you mind discussing about global awareness on the religion tolerance?

Yuven : Oh...that is a great idea. I like it.

The conversation at first exercise above contained interactive language function between Maria and Yuven which has been attained in the greetings function form. "Hello" and "good morning" uttered by Maria to begin her conversation to Yuven. This greeting form as an example of interactive function.

\section{Data 2}

Matilda $\quad$ : Hello good morning, Yovita and Patrisia. How are you?

Yovita $\quad$ : Good morning Matilda, I'm fine.

Patrisia : Good morning Matilda, I'm okay. What about you?

Matilda : I'm fine too.

Matilda : : Alright. Do you agree if we discuss the teenager's life style topic?

Yovita : Yes, I do.

Patrisia : Wow... that is very nice topic to be discussed, Matilda.

The conversation at second speaking exercise contained interactive function between participants which has been attained in the greetings function form. This is also strengthened by data at the third and fourth speaking exercises as follows. 


\section{Data 3}

Natalia : Hello Mario, good morning. How are you?

Mario : Good morning Natalia. I am good. And you?

Mario $\quad$ : Not so bad. Well, Natalia would you like to tell me your financial management strategy? I mean how You manage your money in your daily life.

Natalia $\quad:$ Oh...it is quite difficult telling you the way how I did.

Mario : Please sister, I want to know and follow the way you manage it.

Natalia : I can't tell it to you. I have limited budgeting in my life, what can I share it to you?

Mario : I understand it but you never complaining the money in your daily life. Please sister, share it!

\section{Data 4}

Rikardus : Hello Imelda, good morning.

Imelda : : Morning Rikardus. How are you this morning?

Rikardus : Yah... I am fine. What about you?

lmelda : I am fine too.

Rikardus : That's good. Imelda, would you mind telling me your planning after the graduation from this college?

Imelda : : Alright. Let me tell you.

The third and fourth data above are direct conversations of four participants in practicing personal financial management strategy and entrepreneurship. Participants used "hello" and "good morning" to begin the conversation and create formal situation, flexible and intimate atmosphere. Interrogative sentence "how are you this morning?" indicates the hospitality between participants in asking their colleagues' information in that morning. Indeed, the use interrogative sentence is courteous talk and introductory before focusing on their prime conversation. The interlocutor is not sued for responding by using the complete sentence, such as "I am fine this morning". It may be answered by saying "fine" or "good" and their interlocutor may also re-ask by saying "how about you?" or "and you?".

Greetings functions which categorized into interactive function are also found in the fifth and sixth speaking exercises below. The participants used those utterances in beginning their conversation.

\section{Data 5}

Ivon : Hello Onis, good morning. You okay this morning?

Onis : :Morning. Yah..as you see, Ivon. 
Ivon

: Alright. Onis, we discuss about civic literacy. Okay?

Onis

:Yah...

\section{Data 6}

Thomas : : Hey Delfiani, good morning.

Delfiani : Morning Thomas. How are you?

Thomas : Yah...fine. You?

Delfiani : Fine too.

Thomas : : Delfiani, do you agree discuss civic literacy on a good citizenship topic?

Delfiani : Wow...that's good. I like it.

Thomas : Thank you very much Delfiani. So, what are your thoughts on how to be a good citizen in Indonesia?

The data from the first up to the sixth as stated were obtained from the learning process of English for academic purposes course. Those processes occurred on October and November 2018 at 9.30 until 11.10 a.m. in the Chomsky 1 room. The participants used the interlocutor's first name indicates their hospitality and they have known each other.

All of the above data contained greetings function and courteous function which can be categorized into interactive function. Interactive function is used as a tool for the interaction. This function can be run effectively if a speaker and interlocutor understand the circumstance that allow them to interact (Halliday, 1973: 22-45). Similarly, Ambrosio, Binalet, Ferrer and Yang (2015) claimed that circumstance affects to the interaction between participants. They further described that interactive function enable speakers can interact with their interlocutors in sharing their ideas, collaborate on how they will accomplish their task and use language to maintain conversation. Language variation, such as formal (good morning), informal (yah...fine) at the first exercise, politeness (well, Natalia would you like to tell me your financial management strategy?) at the third exercise and other variations can be used in running the interaction.

\subsection{Informative Function}

Informative function aims to share information which implemented in explaining function and expressing function forms. Expressing function refers to conveying the intention or speaker's wish which generally implemented in the declarative form. The data below as 
examples of expressing function which was done by participants at speaking exercise of speaking for academic purposes course.

\section{Data 7}

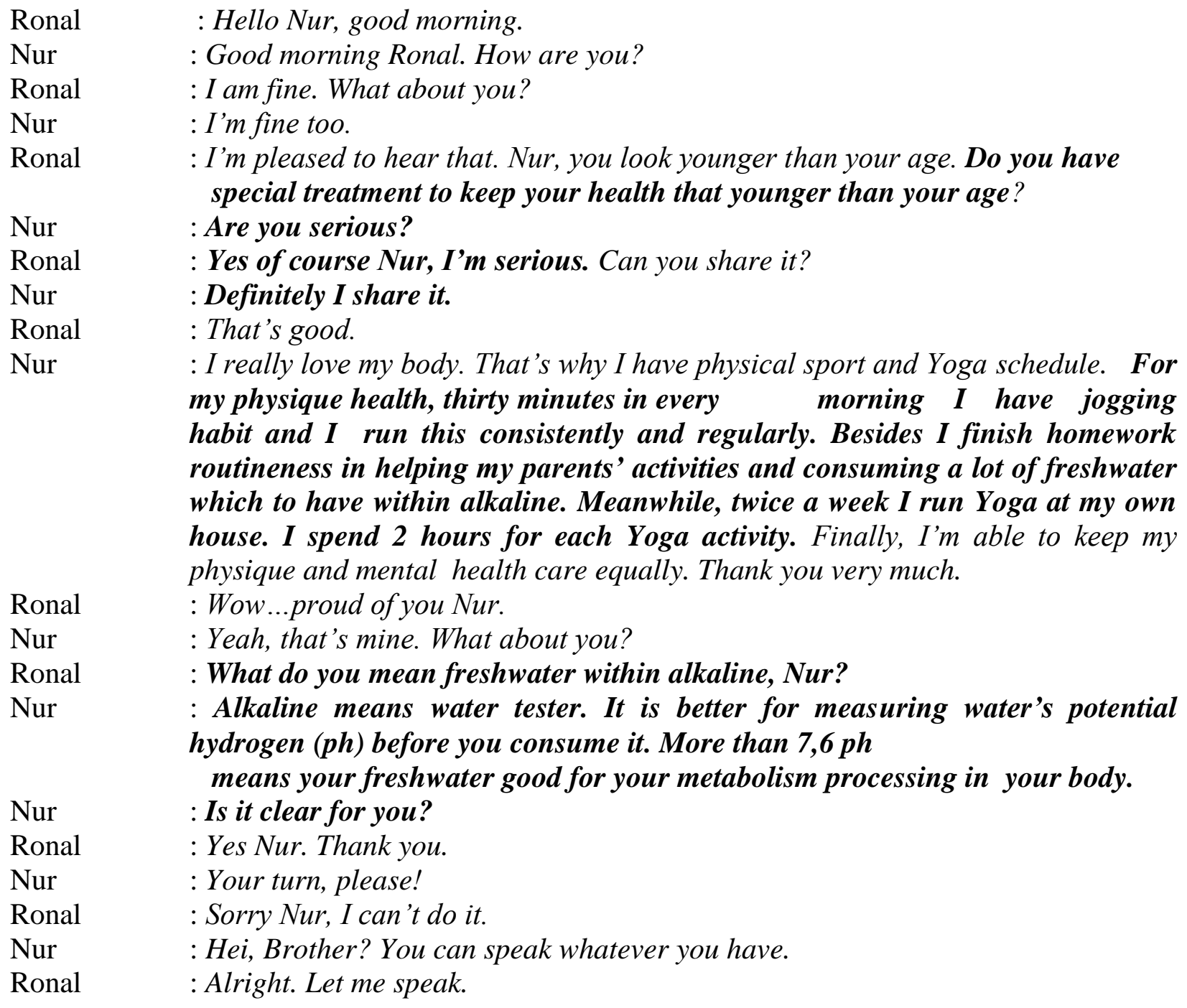

The above data indicates speaker's wish toward interlocutor's strategy in keeping her health. The sentence use in the interrogative form, that is "do you have special treatment to keep your health that younger than your age?". This sentence indicates to the interrogative function and conveying the speaker's wish. Nur then responds with short interrogative sentence, that is “are you serious?" then answered by Ronal with declarative sentence "yes of course Nur, I'm serious". 
It also indicates to the implementation of ensuring function with the sentence uttered by Nur "definitely I share it" or to confirm toward Ronal's wish over health strategy run possessed by Nur. Nur then explains her strategy by using the sentence "for my physique health, thirty minutes in every morning I have jogging habit and I run this consistently and regularly." Nur further explains to Ronal about the strategy in keeping her physique health by using the sentence "besides I finish homework routineness in helping my parents' activities and consuming a lot of freshwater which to have within alkaline. Meanwhile, twice a week I run Yoga at my own house."

By listening well-explanation given by Nur, Ronal responds Nur by using the sentence "wow...proud of you Nur." then Ronal further gives interrogative sentence due to want to know in detail about Nur's strategy by using the sentence "what do you mean freshwater within alkaline, Nur?". Nur re-explains to Ronal "alkaline means water tester. It is better for measuring water's potential hydrogen (ph) before you consume it. More than 7,6 ph means your freshwater good for your metabolism processing in your body." At the end of their conversation, the ensuring function uttered by Nur by using an interrogative sentence "is it clear for you?"

Informative function facilitates information transfer to what kinds of information are transmitted. This is equal with explaining function, that is to share what types of information should be delivered. The understanding of these two functions strongly indicated that language functions are inter-depended with other types, such as persuasive, indicative, manipulative and motivative (Redhead \& Dunbar, 2013; Lee, Choi \& Marqués-Pascual, 2016; Lestari, 2017 ).

\subsection{Manipulative Function}

This function refers to the explaining function that a speaker is asked to be able to manipulate his/her language inadequacy. The following data below indicates the implementation of manipulative function.

\section{Data 8}

Ivon

: Can you start to present your idea?

Onis $\quad$ : Well, I think...a...a...good governance contribute to people life. The consequence, we need to have the strong and what I mean is...a.......eligible leader (local, province, national).Eligible leader...a...how you call it... covers the ideology of transparency, accountability, equality, controlling, and knowledgeable of government administrative systems.

Ivon : : Oh... amazing notion Onis. Thank you very much.

Onis : Thank you but I have the limitation of vocabulary and topical knowledge. 
Ivon

: Oh...don't mention it, you have done it well.

Onis

: Your time Ivon, telling me your opinion on good governance.

Ivon

: Okay...let me tell it to you.

As stated, Onis uses the sentence "well, I think...a...a..." which indicates a diplomacy related to his lacking of fluency, idea and vocabulary. Indeed, the function of this sentence only to maintain positive image of his fluency and topical knowledge. In his further narration, Onis re-uses the sentence "what I mean is...a...a..." which indicates toward diplomacy function on his vocabulary limitation. Then, at the end of his narration, he re-appears manipulative sentence "...a...how you call it" which orientated to the same thing.

The implementation of manipulative function as stated is re-strengthened by conversation data at the continuing of the sixth speaking exercise below.

Thomas : Delfiani your time. Would you like presenting yours?

Delfiani : : Yeah..., how to be a good citizen is top issue to be discussed. To my mind, a good citizen is..a...what we say...indicated by awareness of the rights and obligations for each a citizen. Rights and obligations cannot be separated. Each citizen is suggested to realize his/her obligations toward the state. i.e. income tax, sales, property, real estate tax, obligation toward state and local norms, etc. Tax given engages the government to finance all the infrastructures demanded. Meanwhile norms provided for engaging citizen's social life. Another is right or...a...that's mean.... ...privilege. It is state's responsibility to guarantee citizen's safety life such as education access, excellence healthy care, retirement, and so forth.

Thomas : Wow...excellent Delfiani!

Delfiani : Any comment?

Thomas : No. Thank you.

Delfiani : Great. Thank very much. Your turn, please!. You would be better than mine Thomas : Alright. Let me try it.

In presenting the topic discussed, Delfiani uses manipulative utterance "is...a...what we say..." which indicates her vocabulary limitation to continue her conversation. This sentence is used only for getting the impression as if Delfiani is fluent and having sufficient vocabulary. Manipulative utterance is re-produced at the end of her presentation by using the sentence "another is right or...a...that's mean...a...privilege." Delfiani does not know to express the appropriate synonym of "right" term but she does not stop by assistance the manipulative utterance "a...that's mean...a" for covering her limitation of vocabulary knowledge. 
Based on the above data and continuation of the sixth speaking exercise, it may be concluded that the aim of manipulative function is to seek the compensation on the limitation of fluency aspect in the oral communication. Manipulative function is also related to the other language functions, such as permissive, informative and indicative. Manipulative function refers to the forming impression on fluency that as if a speaker still has an idea in continuing the communication (Akwanya, 2015). A speaker is being diplomatic toward the limitation of idea at his/her mind and attempts to negotiate the pragmatic meaning for the utterances produced.

\subsection{Motivative Function}

Motivative function is frequently used by participants in a number of speaking exercises at the speaking for academic purposes course. The following data indicates the implementation of motivation function as described below.

\section{Data 9}

Ivon

Onis

Ivon

Onis

Ivon

Onis

Ivon

: Can you start to present your idea?

: Well, I think ... a... a... a good governance contribute to people life. The consequence, we need to have the strong and what I mean is ...a..a ...eligible leader (local, province, national). Eligible leader...a ... how you call it... covers the ideology of transparency, accountability, equality, controlling, and knowledgeable of government administrative systems.

\section{: Oh...amazing notion Onis. Thank you very much.}

: Thank you but I have the limitation of vocabulary and topical knowledge.

: Oh...don't mention it, you have done it well.

: Your time Ivon, telling me your opinion on good governance.

: Okay...let me tell it to you.

Ivon used the proper interrogative sentence "can you start to present your idea?" although there is inappropriate diction (start). The word 'start' might be replaced by the word 'begin'. However, Onis still responds that sentence to begin his idea in the conversation. There was limitation found when he presented his idea as given in the sentence "well, I think...a...a...good governance contribute to people life" which must be "well, I think a good governance contributes to people's life". The lacking of fluency is also found in Onis' further sentence "the consequence, we need to have the strong and what I mean is...a...a...eligible leader (local, province, national). Eligible leader...a...how you call it..." which must be "the consequence, we need to have the strong and eligible leader (local, province, national). Eligible leader covers the 
ideology of transparency, accountability, equality, controlling, and knowledgeable of government administrative systems"

The limitation of the oral communication components performed by Onis was still getting motivative utterance from Ivon by producing this sentence "oh...amazing notion Onis. Thank you very much". Then he refuses that utterance by using the sentence "thank you but I have the limitation of vocabulary and topical knowledge" but Ivon does not stop encouraging Onis to practice English continuously by re-producing motivative utterance “oh...don't mention it, you have done it well".

Data on the continuation of the sixth speaking exercise also re-strengthens the implementation of motivative function as produced by Thomas toward Delfiani's presentation through this sentence "wow...excellent Delfiani!". There was limitation of difficulty when Delfiani delivered her idea. Delfiani asked to Thomas by using sentence "any comment?" and Thomas answered "no. Thank you" then Delfiani gave chance to Thomas to deliver his notion about the same topic by using motivative utterance "Great. Thank very much. Your turn, please!. You would be better than mine"

Motivative utterances were also found in the following data as described below.

\section{Data 10}

Agnes : : Hello Yakobus, Elisabeth, good morning.

Yakobus : Good morning Agnes.

Elisabeth : Good morning Agnes.

Agnes : Well. Yakobus and Elisabeth, I would like asking your idea on health service you ever experienced.

Yakobus : That's good.

Elisabeth : Alright. I like discussing it.

Agnes $\quad$ : Oh....that's great friends. So, who is a first speaker? Yakobus or Elisabeth?

Yakobus : Elisabeth first.

Agnes $\quad$ : Hello, Elisabeth? Your turn to present, please! Let us listen to Elisabeth's point of view.

Elisabeth : Okay. Health service is a...a...serious a..problem in our place. government built health service stages in almost places in Indonesia from remote areas to the cities, such as a health clinic, public health center, and hospital. But...a... human resources,such as a... a...doctor, midwife, nurse, lab.analyst are not there.

Yakobus : Well done, Elisabeth.

Agnes : Excellent presentation, Elisabeth.

Elisabeth : Thank you very much. Your time please! 
The above data indicates the implementation of motivative function, as produced by Yakobus and Agnes. Yakobus praises Elisabeth by using a sentence "well done Elisabeth". Likewise Agnes encourages Elisabeth's presentation by using the sentence "excellent presentation, Elisabeth" although there was still found the limitation of fluency when Elisabeth delivered her idea. Elisabeth produced a lot of pauses as given in the data described.

Based on the data given at the continuation of the fifth exercise, sixth and eighth exercise, it may be concluded that motivative functions aims at how to encourage participants to practice English continuously although they have the limitation toward the aspects of oral communication. Motivative function refers to the tolerance toward the limitation of semantic, grammar, vocabulary and fluency toward utterances produced by a speaker. Indeed, a speaker is sued to fulfill some important aspects in the oral communication, namely grammar, vocabulary, comprehension, fluency and pronunciation (Brown, 2004: 171-172; Mckay, 2007).

\subsection{Directive Function}

Directive function is frequently used by participants in their English speaking exercises. This function is not only implemented in the imperative form or affirmative but also frequently refined in the interrogative form as given in the following data.

\section{Data 11}

Maria : Could you give me your opinion on the religion tolerance?

Yuven : Yes of course. personally speaking, I believe that religious belief is mankind's choice and we must respect the diversity of religion celebration. What do you think?

Maria : Well, it seems to me that intolerance of religion endangers our democracy and society disarrangement in our country.

Yuven : That's not the way I see it. Religion tolerance as source of the unity.You see, how Christian respect Moslem's celebration and vice versa.

Maria : Oh... Awesome!

Maria : Ok, so what are your thoughts on religion intolerance occur in certain places in the world?

Yuven : Well, I think that happens less of tolerance values. We need to promote respect the diversity on the religion celebration. You with me?

Maria : : Yes, I do but how do we promote it?

Yuven : Welcoming all people who come to our place and let them celebrate their own religion's celebration

Maria : Only that one?

Yuven : I don't think so. If you are a Moslem fellow, you may give Christmas card for Christian

Maria : Thank you very much Yuven. 
Yuven : You're welcome.

The above data shows that, Maria is asking Yuven's opinion on the topic they are discussing by using modals 'would' in the sentence "would you give me your opinion on the religion tolerance?" which the usage of modals 'could/would' is more polite than 'can/will'. Although there is no social status difference that Maria is higher than Yuven. Then, Yuven affirms that sentence by producing a certain utterance "yes of course".

Yuven re-asks Maria to give her opinion by using interrogative sentence "what do you think?" and Maria responds by producing the sentence "well, it seems to me that intolerance of religion endangers our democracy and society disarrangement in our country." Asking function is re-strengthened when Maria uses interrogative sentence "ok, so what are your thoughts on religion intolerance occur in certain places in the world?" Yuven responds by using the sentence "well, I think that happens less of tolerance values. We need to promote respect the diversity on the religion celebration. You with me?"

As data stated, it may be concluded that directive function aims to make the interlocutor does something wished by a speaker. Speaker affects the hearer's comportment (Leech, 1974: 47- 49).

\section{Novelties}

After analyzing the conversations done by participants, the researchers found the new two types of language functions, namely manipulative and motivative. These functions have a vital role in the achievement of participant's functional communication. Manipulative and motivative function can be identified as a great tactic for a speaker in covering his/her lacking of vocabulary, grammar, fluency, comprehension in making paraphrasing and topical knowledge.

These two functions are also cannot be separated from other types of language functions, such as interactive, informative, directive and so forth. The understanding of language functions enables speakers to have the functional communication and cope better with the communication problems they encounter in their interaction.

\section{Conclusion}

The prime function of language in everyday contexts is concerned broadly with the social life. There is inter-dependency between function of language and human's life. Human is enabled to convey the information to each other or request services of some kind in a variety of 
situations. There are five types of language functions used in a sundry of exercises at the speaking for academic courses, such as interactive function, informative, manipulative, motivative and directive function. Those functions are inter-depended in supporting functional communication based on the situation needed. Speaking instructors are suggested to provide concept of language functions in their English speaking process.

\section{References:}

Akwanya, A. N. 2015. Literature and the Possibilities of Language Function. Journal of Studies in Social Sciences, 11 (2), 233-254.

Ambrosio, Y. M., Binalet, C., Ferrer, R., and Yang, J. 2015. Analysis of Language Functions in Children's Classroom Discourse. International Journal of Education and Research, 3 (2), 105-114.

Azizifard, F. and Jalali, S. 2012. Context and Humor in Teaching Language Functions. Theory and Practice in Language Studies, 2 (6), 1191-1198. https://doi.org/10.4304/tpls.2.6.1191-1198

Brown, H. D. 2004. Language Assessment: Principles and Classroom Practices. New York: Addison Wesly Longman Inc.

Brown, H. D. 2007. Principles of Language Learning and Teaching. Fifth Edition. San Fransisco: Pearson Education, Inc.

Celce-Murcia, M. 2001. Teaching English as a Second or Foreign Language. Third Edition. New York: Heinle\&Heinle Ltd.

Dickinson, P. 2013. "B/w U \& me": The Functions of Formulaic Language in Interactional Discourse on Twit er. The Linguistics Journal, 7(1), 7-38.

Halliday, M. A. K. 1973. Explorations in the functions of language. London: Edward Arnold.

Harmer, J. 2007. How to the Practice of English Language Teaching. Fourth Edition. Edinburgh Gate: Pearson Longman.

Imaniah, I. and Dewi, N. F. K. 2017. The student's academic speaking skill achievement in terms of communication, personality and gender. The Asian EFL Journal, TESOL Indonesia International Conference Edition, 8, 28-35.

Jakobson, R. 1987. Linguistics in Literature. London: Harvard University Press.

Lee, J. S., Choi, J. Y., and Marqués-Pascual, L. 2016. An Analysis of Communicative Language Functions in the Speech Patterns of Bilingual Korean and Mexican Immigrant Children. New Approaches in Educational Research, 5(2), 66-73. http://doi.org/ 10.7821/naer.2016.7.193

Leech, G. 1974. Semantics. England: Penguin Books.

Leong, Lai-Mei. and Ahmadi, S. M. 2017. An analysis of factors influencing learners' English speaking skill. International Journal of Research in English Education, 2(1), 34-41. https://doi.org/10.18869/acadpub.ijree.2.1.34

Lestari, D. 2017. "Penggunaan Fungsi-Fungsi Bahasa di Bidang Tata Hidangan dalam Pembelajaran Keterampilan Berbicara Bahasa Inggris" (disertasi). Denpasar: Universitas Udayana. 
Lestari, D., Suastra, I. M., Pastika, I. W., and Sedeng, I. N. 2017. Developing A Method of Learning English Speaking Skills Based on the Language Functions Used in the Food and Beverage Service. E-Journal of Linguistics, 11 (1), 70-79.

Kayi, H. 2006. Teaching Speaking: Activities to Promote Speaking in Second Language. (serial online), November., [cited 2017 October 29]. Available from: http://iteslj.org.

Kemenristekdikti. 2012. Kerangka kualifikasi nasional Indonesia. Jakarta: Kementerian, Riset, Teknologi dan Pendidikan Tinggi.

Mckay, P. 2007. Assessing Young Language Learners. Cambridge: Cambridge University Press.

Menggo, S. 2018. English Learning Motivation and Speaking Ability. Journal of Psychology and Instructions, 2( 2), 70-76.

Menggo, S., Suastra, I. M., Budiarsa, M., and Padmadewi, N. N. 2019. Needs Analysis of Academic-English Speaking Material in Promoting 21st Century Skills. International Journal of Instruction, 12(2), 739-754. https://doi.org/10.29333/iji.2019.12247a

Parpalea, M. 2011. The Functional Approach in German Linguistics: Philology and Cultural Studies. Journal Transilvania Univeristy of Braşov, 4 (2), 115-122.

Redhead, G. and Dunbar, R. I. M. 2013. The Functions of Language: An Experimental Study. Evolutionary Psychology Journal, 11(4), 845-854.

Sarwadi, S., Yadnya, I. B. P., Beratha, N. L. S., and Puspani, I. A. M. 2019. Function and Meaning of Metaphors in The Palm-Leaf Manuscript of Cilinaya Written in Sasak Language and its Translation. E-Journal of Linguistics, 13 (1), 43-55. https://doi.org/10.24843/eJL.2019.v13.i01.p05

Tarigan, H. G. 2015. Berbicara Sebagai Suatu Keterampilan Berbahasa. Edisi Revisi. Bandung: Angkasa.

Tribus, A. C. 2017. "The Communicative Functions of Language: An Exploration of Roman Jakobson's Theory in TESOL" (Thesis). Brattleboro, VT: SIT Graduate Institute.

\section{Acknowledgements}

The researchers would like to gratefully acknowledge the Indonesia Endowment Fund for Education (LPDP) and Rector of Universitas Katolik Indonesia Santu Paulus Ruteng, Flores for their support and grant given in finishing this research.

\begin{tabular}{|l|l|}
\hline & $\begin{array}{l}\text { Sebastianus Menggo was born in Urang, 02 October } 1980 \text { and received his } \\
\text { undergraduate degree of English education at Kanjuruhan Malang } \\
\text { University in 2015, post graduate of English education at Universitas } \\
\text { Pendidikan Ganesha Singaraja in } 2013 \text { and doctorate of linguistics at } \\
\text { Udayana University Denpasar in 2019. Sebastianus Menggo is an English } \\
\text { lecturer at department of English education, Universitas Katolik Indonesia } \\
\text { Santu Paulus Ruteng, Flores since 2005. He has participated in a number of } \\
\text { national and international conferences, academic workshops and published } \\
\text { many proceeding articles and journal articles either national, national } \\
\text { reputation or international and international reputation. Recently, } \\
\text { Sebastianus has blessed two children, Benedicto Chrisetia Pradana (15 }\end{array}$ \\
\hline
\end{tabular}




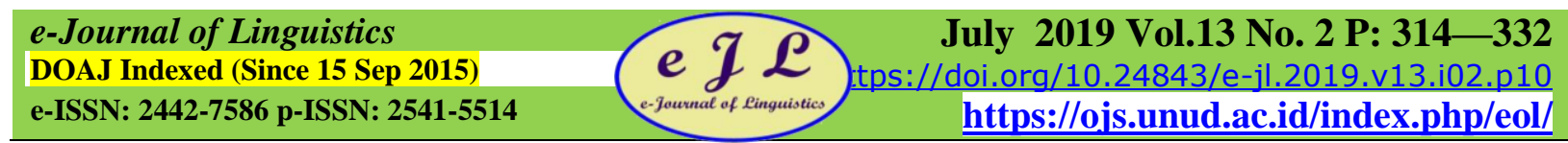

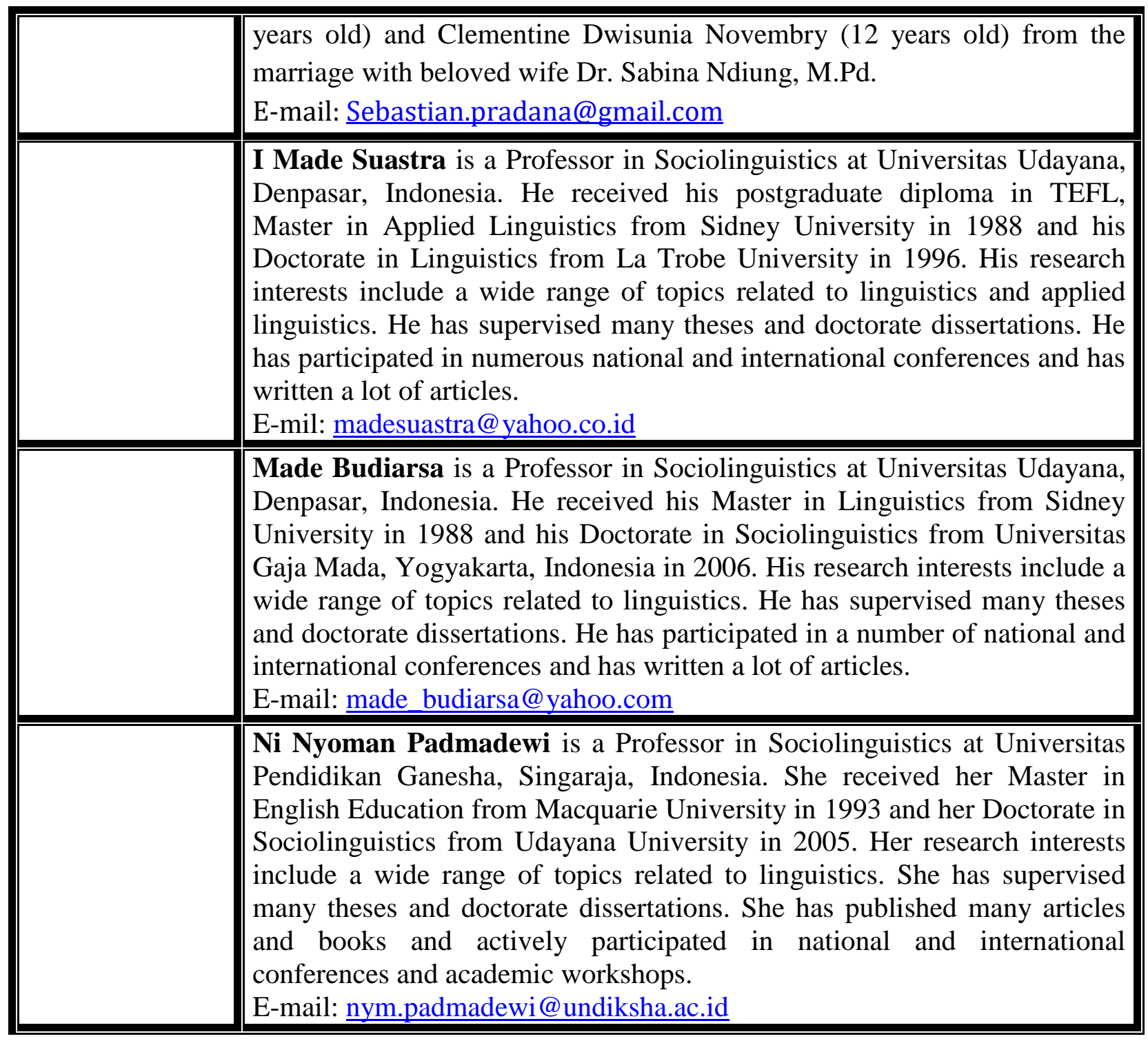

